\title{
PERGUNTA PELO OUTRO O OUTRO NA FILOSOFIA DE HEGEL, HUSSERL, HEIDEGGER E LEVINAS
}

Ulrich A. Müller**

SÍNTESE - Este texto trata da questão da percepção do "outro" no pensamento de Hegel, Husserl, Heidegger e Levinas, evidenciando os paradoxos que surgem quando a razäo imanente pretende apropriar-se da questão e realçando as teņsões presentes na própria questão, sugerindo dimensōes alternativas da raçionalidade para a abordagem do problema.

PALAVRAS-CHAVE - Outro. Razăo. Fundamento. Imanência.
ABSTRACT - This paper discusses the perception of "the other" in the works of Hegel, Husserl, Heidegger, and Levinas, bringing to the fore the paradoxes that arise when the immanent reason tries to appropriate the issue. It also focuses on the tensions inherent in the issue and puts forward alternative outlooks on rationality. KEY WORDS - The other. Reason. Grounding. Immanence.

Na filosofia moderna, desde Descartes, o significado do outro ficou claramente para trás; fato esse que se vincula à autoconsciência da razão filosófica nela articulada. O pensamento contemporânẹo está buscando ainda as possibilidades de sua auto-fundamentação, querendo deduzir daí a base de sua autodeterminação. Ao meu ver, esse empreendimento é conșeqüência de uma muita específica interpretação do cogito cartesiano, que concebe a possibilịdade da liberdade na independência do sujeito determinador de si mesmo. A filosofia da subjetividade, oriunda desta perspectiva, tenta compreender sua própria constituição a partir de si mesma, topando, porém, permanentemente com os limites de sua autodeterminabilidade justamente ali onde ela busca compreender os pressupostos de seu ponto de partida. Em última instância, o problema de Descartes fora já aquele da possível ou, até mesmo necessária confirmação da certeza de si mesmo de um pensamento que faz sua auto-experiência.

As dificuldades que aí surgem não têm importância apenas teórica, mas ainda um significado fundamental para a prática do convívio humano. Pois, a ética de-

* Texto traduzido do alemão por Hans-Georg Flickinger e Muriel Maia Flickinger. Este texto foi publicado pela primeira vez em: PIZZI, Jovino, KAMMER, Marcos. Ética, economia e liberalismo. Pelotas: Editora da UCPel, 1998, p. 77-97.

** Professor da Universidade de Kassel (Alemanha).

\begin{tabular}{|l|l|l|l|l|l|}
\hline VERITAS & Porto Alegre & v. 44 & n. 2 & Junho 1999 & p. 311-325 \\
\hline
\end{tabular}


duzida do modelo de autofundamentação gira, em última instância, em torno do mesmo problema que move também o sujeito. A saber: quais as condições que permitem a minha autocompreensão e, com isso, a compreensão do outro? Por que motivos deveria eu querer compreendê-lo se encontro meu fundamento em mim mesmo? Por que eu, que sou um sujeito autodeterminado, deveria ainda colocar-me frente a mim, expondo-me às minhas próprias perguntas?

Foi sobretudo a filosofia do sujeito, desde Leibniz até Hegel, que se preocupou com essa problemática da autofundamentação, seguindo, com isso, de modo implícito, os caminhos abertos pelo cogito cartesiano. Nesta perspectiva, o significado do outro explica-se pela função a ele adscrita por parte do sujeito. Isso assegura a verdade do sujeito, sem corresponder, porém, a todas as nossas experiências. Pois, o encontro com o outro não acontece única e exclusivamente a partir de minha iniciativa própria. O encontro com o outro conduz, muitas vezes, a surpresas, subjuga-me, produz em mim inquietação ao levar-me a esquecer as minhas intenções. O encontro com o outro possibilita-me, talvez, chegar enfim a entender, pela primeira vez, as minhas próprias intenções, seguindo os interesses que me movem.

Assim, por exemplo, não posso pressupor que, apenas com a minha fala, possa fazer solicitações ao outro, mas devo contar, também, com a fala do outro em relação a mim, a fim de levá-lo a ouvir a solicitação que tenho em relação a ele. (Com isso, pressuponho que o ouvir do outro ultrapasse seu caráter de mero fato fisiológico; mais ainda, pressuponho que o funcionamento da fisiologia baseie-se em outros pressupostos que a fisiologia mesma não seria capaz de esclarecer. Formulado de outro modo: os tons que penetram dentro do ouvido precisam já significar, para nós, algo a priori, a fim de poderem tomar seu caminho através do canal auditivo).

Que nos espantemos frente a fenômenos antes desconhecidos, que não possamos forçar o sono, evocar, pela vontade, o amor, são outras experiências nas quais se mostra que nossas experiências ultrapassam o por nós querido, porque o outro existe. Que ele exista, mostra-se mesmo como condição para que determinadas experiências possam ser feitas. Nessas experiências, não dispomos, porém, sobre o outro. Um pensamento que, aceitando o procedimento cartesiano, conclui que a consciência subjetiva seja auto-suficiente, exclui o outro, porque esse escapa a essa determinabilidade racionalista.

Ainda assim, o tema da "experiência do outro" nunca desapareceu na filosofia a qual se confronta mesmo, em primeira linha, com a questão de como - a partir do sujeito - essa experiência pode ser compreendida e trabalhada. Quer dizer, a fenomenalidade do outro é refletida pelo sujeito enquanto mera experiência que eu faço. Eu sublinho, com isso, a idéia da factibilidade de experiências que excluem necessariamente o que a elas se opõe. Pois, a experiência da autoconsciência suspensa através da reflexão - como o nomeia Hegel - pressupõe uma experiência (Erfährnis) que, no sentido de Kant, é o que, seja lá como for, torna o mundo pensável. O mundo não é ainda mundo quando ele nos encontra, nós o fazemos tal e isso sempre de novo. Logo, algo que me resiste antecede à experiência consciente, a qual só na sua repetição refletida tornou-se minha experiência. 
Foi a religião que se preocupou com tais experiências, atribuindo-lhes dignidade extraordinária. O próprio Descartes procurou resolver o problema da autofundamentação e da experiência do outro através da separação categórica entre uma substância infinita e uma finita. Essa separação transformou-se em muitas outras cisões, as quais foram necessárias a fim de que a própria consciência pudesse indicar seu lugar em uma ordem das coisas. Essa consciência se autodetermina ao longo do processo do mundo por ela constituído e busca, desse modo, apresentar-se a cada nova experiência enquanto sujeito ativo. Porém, a experiência do outro torna visíveis os limites dessas possibilidades. A determinabilidade desses limites é um momento essencial no esclarecimento da questão de como se experimenta o encontro com o outro. Enquanto o sujeito "faz suas próprias experiências", isto é, no sentido contemporâneo, do ser sujeito autoconsciente de suas experiências, esse sujeito percebe as fronteiras entre si e o outro como suas próprias fronteiras (ou como fronteiras que são suas próprias). Se a consciência vir-se exageradamente impressionada pela experiência, a ponto de sentir-se por ela violentada, eis que essas fronteiras autodeterminadas ver-se-ão fundamentalmente feridas. Na medida, porém, em que com isso os fundamentos da autodeterminação vêm-se arrastados pela paixão, o sujeito não estará impressionado apenas de modo passageiro, mas a estrutura ela mesma da subjetividade estará sendo colocada em cheque. As conseqüências daí provindas tocam, de modo radical, o fundamento da autoconsciência que pensa carregar em si a sua própria origem. A primazia da experiência leva à lesão da integridade da autoconsciência devido a que essa só muito tardiamente faz seu, o que lhe vem ao encontro. A filosofia de Levinas, assim como a psicanálise, falam de um trauma que deixa atrás a experiência. É claro que sem esse assalto do outro tampouco seria possível a reflexão da consciência sobre si mesma.

A primazia dessa experiência é o que, na verdade, marca a reflexão da experiência em geral. A psicanálise segue, com isso, os trilhos da religião tentando abrir a um saber o a priori dessa experiência. Dessa maneira, o conhecimento é roubado da possibilidade de certificar-se de seus próprios pressupostos.

A pergunta pelo outro leva-nos ao cerne metafísico da filosofia ocidental; pois à sua luz não parece nem que o próprio saber seja ontologicamente fundamental, nem que a origem da consciência subjetiva possa vir a ser refletida. $O$ fato de a Teologia encontrar espaço neste campo, deve-se também à própria postura da filosofia que pouco atentou à anterioridade da experiência negligenciando seu significado. Pergunta-se até que ponto uma filosofia com pretensão da fundamentação imanente de sua verdade poderá sequer reconhecer a primazia da experiência. Com razão, a partir de uma tal perspectiva deve-se manter a questão da Filosofia do sujeito, isso é, de como a anterioridade de uma experiência poderia tornar-se significativa. Contra minha própria concepção retomarei, ao fim desta exposição, essa pergunta que, ao fundo, caracteriza o paradoxo da razão, a saber, sua autodeterminação à base de um fundo indeterminado. (Kant substituiu desse modo a velha Metafísica por uma fundamentação paradoxal da razão.) Quando pergunto pelo outro, portanto, não me coloco nem ao lado da filosofia que obedece à exigência de determinar qualquer experiência em termos racionais, nem 
tampouco entrego-me à crença em uma experiência religiosa que se articula em confissões e se esforça também em descrever aquilo que se rouba justamente à reflexão articulada na língua. A pergunta pelo outro toma a si um problema metafísico, a fim de esclarecê-lo filosoficamente. Em vista disso, suponho que a filosofia se esforce por achar o caminho em cujo fim o voltar-se ao outro encontra-se já plantado na fé. Os traços desta experiência só se deixam perseguir em nível filosófico, pois a filosofia - como o faz Descartes - preocupa-se com a tematização discursiva do contestável. A Teologia, por seu lado, faz a tentativa paradoxal de abrir um campo de saber precisamente em relação a uma experiência a qual escapa da tradicional pesquisa científica.

Tendo escolhido quatro filósofos como referencial de minha investigação, aprofundo minha pergunta quanto à possibilidade do encontro com o outro, a partir da perspectiva da filosofia. Com isso, desejo manter a tensão produzida entre saber e não-saber - poder-se-ia dizer, também, entre consciente e inconsciente. Essa tensão permite tornar clara a produtividade de experiências que seriam excluídas pelos preconceitos racionalistas. Ao mesmo tempo, faz-se claro, nessa tensão, que a razão depende dos momentos de sua questionabilidade para fazer-se valer. A verdade da razão forja apenas o horizonte que abre os caminhos. Em contrapartida, a confissão dogmática em favor da razão, a expectativa de um determinado fim último da prática racional, só ocultam e deformam aquilo que seria exatamente a chance de abrir a limitação do entendimento. A razão não deve ser detida, mas se a deve fazer valer através de diferenças. O fato da impossível certeza da razão abre um abismo, onde se busca fundamentação.

Essas diferenças tornar-se-ão claras pela minha exposição de quatro perspectivas em relação ao encontro com o outro. As perspectivas baseiam-se em concepções filosóficas bem diferentes. Nelas, formam-se, simultaneamente, os diversos esboços dessas diferenças, fazendo transparecer que o debate em torno da pergunta pelo outro representa um momento crucial da constituição da sujeitividade. Ali, onde o outro torna-se um problema da filosofia, o pensamento, entretanto, dele se apropria de modo dominador, através da determinação, perdendo, porém, algo do outro, o qual justamente nos levou a pensar.

A presente investigação foi acionada ou desencadeada pelos trabalhos de Emmanuel Levinas. Seu pensamento estimulou-me a perguntar por quais caminhos o outro e o encontro com o outro poderiam tornar-se pensáveis e experimentáveis.

\section{1 outro na Fenomenologia de Hegel}

A Fenomenologia do espínito de Hegel descreve o caminho de constituição de um sujeito absoluto, desde a certeza sensível até o Espírito perfeito. Uma incisão decisiva neste caminho é a constituição da consciência a qual é capaz de se autoconceber enquanto consciência, porque encontra uma outra consciệncia. Ao longo dessa reflexão dialética sobre si mesma, a consciência sai de si para voltar, finalmente, a si mesma. A fim de conseguir uma noção de si mesma, a consciência é obrigada a separar-se de sua imediata certeza sensivel. Para que isso possa acontecer, contudo, precisam ser colocadas algumas condições que preparem, de an- 
temão, o campo, a fim de que a consciência avance para fora de uma sua imediatez. Esse passo da consciência para fora de sua própria limitação é, penso eu, o ponto de partida decisivo para o seu subseqüente caminho em direção ao espírito absoluto. Pois, na medida em que a consciência produz - como que através de sua capacidade de sair de si - sua própria possibilidade de se autodeterminar, põe-se, por sua própria atividade, na situação de efetuar outras determinações. 0 contínuo desdobramento do mundo pode começar no momento em que a consciência encontra-se a si mesma, na primeira dobra. O mundo está, portanto, dobrado na consciência e vice-versa, a própria consciência começa a diferenciar-se através do desdobramento do mundo. (A imagem barroca da dobra, eu a extraio da filosofia de Leibniz que, ao fundo, expõe na Monadologia a estrutura deste processo, sem expor sua genealogia.) A consciência imediata distancia-se de si mesma a fim de se compreender e tornar-se com isso, simultaneamente, pela primeira vez consciência que terá sido.

$\mathrm{Na}$ forma complicada do tempo, que aqui escolhi, deixa-se apresentar o problema ao qual desejo chamar atenção. Hegel descreve, na verdade, uma curva paradoxal sem a qual, no entanto, nenhum entendimento teria a condição de se autocompreender. A consciência que se compreende a si mesma precisa, de antemão, pressupor aquilo, do qual tem de desenvolver seu conceito - a saber, o de ser consciência. Hegel alerta que uma consciência é já, desde sempre, consciência de si meșma; do contrário, não seria consciência. Cada apreensão consciente de algo coloca-se em relação àquilo que conhece, a fim de - seja lá como for - poder conhecer. A dificuldade com que nos vemos confrontados nessa curvatura da Fenomenologia do espínto é aquela de que a descrição da consciência imediata, feita ao longo das cem páginas anteriores, torna-se possivel apenas a partir de uma perspectiva ulterior à própria descrição. O caminho até aí é ademais, nesse caso, um caminho especulativo, tanto que o próprio Hegel precisa pressupor que a consciência produzirá para si seus próprios pressupostos. (Tanto do ponto de vista da história da filosofia, quanto do psicanalítico, essa reflexão lógica é elucidativa para qualquer caracterização auto-referenciạl. Pois, em cada história que é contada, seja ela individual ou coletiva, o sujeito produz para si uma história, através da qual ele narra a si mesmo como chegou ao ponto de vista presente. Com a história que nos situa num contínuo do tempo, criamos para nós a nossa origem). À base desse pensamento, de que a própria razão produz seu fundamento, constrói-se a filosofia da consciência, e a Fenomenologia do espírito de Hegel é o modelo logicamente pensado da constituição subjetiva da consciência. Hegel ousa, com isso, investigar a gênese da mônada leibniziana, a qual só havia exposto a estrutura atemporal e inespacial e as fronteiras da atividade da razão. A Fenomenologia descreve, de certo modo, a história da constituição que a mônada narra para si mesma, a fim de conseguir para si um lugar próprio no mundo das outras coisas.

Enquanto Leibniz ocupa-se apenas à margem com a gênese da consciência racional, escapa-the um problema com o qual se defronta a Fenomenologia de Hegel. Possivelmente, a ousadia da Fenomenologia hegeliana situe-se justo na descrição de um caminho, cujas estações singulares ligam-se através de conexões causais. Na passagem da "consciência imediata" para a "autoconsciência" vemo- 
nos confrontados com uma tal conseqüência. Explico. Através de certos processos, a consciência imediata topa com uma situação cuja conseqüência lógica é o seu sair para fora de si mesma. Hegel o descreve como um "movimento de forças" no íntimo, as quais colocam-se frente a frente, criando uma tensão. A tensão assim produzida atinge um grau que exige o reconhecimento de uma diferença que brota do interior, como se fosse um poder exterior necessário. Esse excitante pensamento de Hegel apresenta-se-nos na imagem de um "salto", através do qual a consciência é confrontada com o outro. Da diferença do "assemelhar-se a si mesmo" faz-se a diferença em relação a uma outra consciência. Estando imediatamente em mim, empurro-me de mim mesmo. "Eu, de igual nome...; porém, esse diferenciado, posto como desidêntico, é imediatamente, na medida em que é diferenciado, sem diferença para mim." '" Só a confrontação com uma outra consciência deixa a consciência perceber a diferença. Só essa confrontação deixa a consciência conhecer-se a si mesma.

Nesse caminho, a consciência faz uma experiência, através da qual só agora começa, a se compreender a si mesma. Para chegar a essa determinação do próprio Selbst, é necessária a experiência de que existe uma outra consciência. Só através da experiência com a outra consciência pode a consciência, enfim, penetrar no "reino natural da verdade"; pois, só agora sabe-se a consciência enquanto 0 verdadeiro, porque 0 verdadeiro tornou-se para ela conceito. A experiência do outro integra-se, de certo, de imediato nesse conceito, aniquilando, com isso, sua particularidade. O drama que se desenvolve, na medida em que a consciência "sacrifica sua vida" (Gadamer), a fim de ultrapassar a tensão interna, é imediatamente suspenso na história da autoconsciência, que sabe esclarecer a si mesma a necessidade lógica de ter chegado a si mesma. O outro torna-se, assim, de imediato um momento da consciência autocognoscente, já que a experiência ameaçadora do outro torna-se uma condição necessária para que a consciência de modo geral exista. A experiência da outra consciência torna-se um momento da autoconsciência, o outro, por sua vez, a condição de mim mesmo, por mim suspensa. Através da suspensão, porém, a autoconsciência apropria-se de sua próprias condições e transforma $o$ acontecimento existencialmente ameaçador em uma determinação em si mesmo. O outro é a outra consciência para mim e, com isso, uma condição reconhecida. Reconhecimento esse que se evidencia, porém, como tentativa posterior de usurpar a própria condição. "A autoconsciência é em si e para si, na medida em que é através do que ela é para um outro em si e para si; e ela é somente enquanto uma consciência re-conhecida." 0 reconhecimento se dá através da suspensão - que ocorre na negação da outra consciência. Mediante a suspensão da experiência do outro, a experiência é transformada, posteriormente, num momento da própria constituição. (A psicanalista Jessica Benjamin reconhece, nesse processo, o desenvolvimento do bebê no espelho de seu ser materno à frente. Justo isso, porém, aponta o problema de se tomar como ponto de partida exclusivo a relação de espelhamento, porque os sujeitos não podem mais separarse um do outro, como gêmeos). ${ }^{3}$

1 HEGEL, G. W. F. Die Phänomenologie des Geistes, p. 135.

2 Idem, p. 144.

3 Ver Jessica Benjamin, The bonds of love, capitulos 1 e 2. 
Só posteriormente, a consciência se terá percebido em sua negação, a fim de novamente chegar a si mesma, por meio de outro. Só o reconhecimento do outro leva ao conhecimento da consciênciá quanto a si mesma. Ela se reconhece, portanto, no outro enquanto ela própria. Com isso, ela conhece o outro enquanto negação de si mesma. Pois, a consciência, inesperadamente quase que sai de si; caracteriza, porém, mais tarde, esta saída de si enquanto condição necessária de seu ser.

Isso é louco, no sentido de deslocado, na medida em que não se pode saber por que a consciência em seu estar em si imediato teve de exigir de si essa ousadia, já que com isso, sua vida vê-se ameaçada. Pois através do salto que realiza, ela põe em perigo o seu próprio ser, cuja tarefa, até aí, consistia exclusivamente em se autopreservar. A consciência abandona seu ser a fim de conquistar-se de novo, em nivel mais elevado. Da perspectiva que se volta para trás, esse caminho torna-se claro. Ainda assim, a experiência da crise torna a tarefa do ser presente pouco esclarecedora. É preciso que algo vindo de fora dê entrada para que a consciência assuma a própria ousadia de encontrar uma outra consciência. É preciso, portanto, que do outro emane uma atratividade ou uma promessa, que deixe a experiência parecer, de algum modo, possível.

\section{Do ego ao alter-ego, nas Meditações cartesianas de Husserl}

A Fenomenologia de Husserl liga-se imediatamente às considerações cartesianas. O "Eu penso", o "ponto arquimédico" de Descartes, através do qual a certeza da própria existência é ligada ao pensamento, forja em Husserl aquela "evidência", através da qual os fenômenos do mundo conseguem afinal conectar-se: "Qualquer evidência é auto-experiência de um sendo ou assim sendo, ao modo de um isso mesmo enquanto certeza plena desse ser, a qual exclui, portanto, qualquer dúvida". ${ }^{4}$ Ao fundo, o Eu, enquanto um evidente "sendo assim" (So-Seiendes) garante a concatenaçăo de tudo aquilo que é através da experiência. O Eu é o ponto de partida e o fiador da certeza do ser.

Cogito é, para Husserl, garantidor da verdade que protege contra fenômenos enganadores, porque, no "Eu" pensante, a atividade do conhecer e o objeto do conhecimento formam uma unidade. Esse é o lugar do ponto de vista subjetivo, único no mundo dos fenômenos. O "Eu" interconecta, desse modo, em si, em primeiro lugar, a "unidade do vivido", torna-se, em segundo lugar, "substrato das habitualidades" e pode com isso, em terceiro lugar, relacionar a si, monadicamente, os fenômenos do mundo.

As limitações das próprias possibilidades que ganham sua forma na substância infinita de Deus, na terceira meditação de Descartes, vêem-se suspensas por Husserl, na mônada do próprio Cogito. A própria dúvida torna-se a expressão de uma certeza do cogito, e não necessita, nessa medida, qualquer outra instância além. Husserl esboça um idealismo transcendental da imanência que reconduz cada fenomenalidade no mundo para seu ponto de partida no Ego cogito. Por isso, também, o outro, introduzido por Descartes - embora também singular - é um

4 E. Husserl, Cartesianische Meditationen, p. 17. 
fenômeno que é apresentado pelo Eu no sentido de já ter sido antes posto. Husserl diferencia entre "o posto à frente" e os "pós-figurados", a fim de fazer compreensível a duplicidade da experiência. Por um lado, o Ego consegue produzir experiências pela gênese ativa, configurando, assim, fenômenos, de modo autônơmo; por outro lado, o Ego também é forçado a uma gênese passiva, pois certas experiências lhe acontecem. Essa passiva efetuação posterior transforma-se, entretanto, através do cogito em uma re-apresentação. Por essa razão, todas as representações são potenciais pós-figurações. Em oposição â Fenomenologia de Hegel, Husserl percebe, entretanto, que existe a possibilidade de uma experiência passiva, que se opõe ao pensar ativo do Ego. Através da polarização em uma experiência passiva e numa ativa, Husserl procura dar conta do que a Fenomenologia hegeliana abre mão; a saber, daquela experiência anterior, impulsionadora da consciência que acontece antes da experiência refletida. Pois, mesmo isso que sucede ao Ego como experiência, é concebido pelo Ego como sucedido. Esse modo de experiência põe a evidência do Ego como pressuposto. Passividade e atividade do objeto da experiência referem-se sempre, em Husserl, ao Ego pressuposto. Sua polaridade organiza-se através do ponto de partida desse núcleo de evidência. Conseqüentemente, também à experiência passiva subjaz um pressuposto, que sedimenta em geral o fundamento para a experiência. Por isso, juntamente com 0 cogito, encontra-se ao fundo da passividade uma atividade evidente. "Todo conhecimento remete a um conhecer primordial; o que chamamos conhecido, possui, porém, a forma estrutural do já ter conhecido, a forma do objeto ou, mais precisamente, a forma de um objeto espacial, cultural, instrumental etc."5

Para Husserl, tudo o que experimento é, portanto, já "presente para mim". A conseqüência desse pensamento é que a toda experiência subjaz um horizonte de experiência comum do Eu e do objeto. Husserl fala aí de uma "corrente de vivência", através da qual o Cogito está necessariamente interligado com os objetos por ele experimentados, a fim de poder experimentá-los. A "camada uniformemente interconectada do fenômeno mundo" de Husserl, na qual também o Ego está mergulhado, lembra-nos o problema de como a experiência em geral poderia ser pensada e, mais ainda, de como poderia ser pensada a experiência de um outro ser humano.

Através da "corrente de vivência", o Eu está conectado, também, com o outro e pode, por isso, vivenciá-lo enquanto um outro ser humano. Essa experiência diferencia-se de outras experiências pelo fato de que para mim o outro dá entrada enquanto "análogo do Eu-mesmo (Selbst)", quer dizer, para mim, sua presença corporal mostra-se de modo peculiar, em relação a minha presença imediata. Enquanto a presença do Ego é, de fato, evidente, trata-se na outra presença de uma co-presença. Enquanto o Eu pode dizer de si "eu sou", o Eu pode dizer do outro apenas que ele "está como Eu". Nenhum Eu pode dizer de um outro Eu que esse é imediatamente para si. Ele pode apenas supor que com outro Eu seja também assim, porque no Eu é assim. Essa conseqüência baseia-se numa analogia. A evidente certeza só é possivel, porém, ao Eu para a si mesmo. Nessa medida existe o outro no meu ser apenas enquanto "ser com" (Mit-Sein). A presença

5 Idem, p. 82. 
corporal mostra-se na evidência do "modo aqui", onde o Eu pensante sabe-se a si mesmo em relação ao "modo lá" do oụtro, onde o Eu pensante representa apenas um analogon de si mesmo.

Enquanto o eu se sabe presente, pode saber o outro somente enquanto "Copresente". O outro é "apresentativamente espelhado, e não original". ${ }^{6}$

Passo a passo, torna-se claro de onde se arranca a experiência do outro em Husserl. O outro é por mim experimentado enquanto o outro de mim mesmo e é, deste modo, uma imagem re-apresentada de meu "eu próprio". O outro é o outro apresentado por mim para mim. Ele é "alter ego" do Ego, nessa medida um Ego por ele produzido. O Ser-com do outro, no mundo comunitário, é garantido através da esfera primordial que o coloca ao meu lado para, de certo modo, tornar, a mim, experimentável, de modo geral, o outro enquanto outro. (Talvez possa ajudá-los se vocês se representarem o mundo enquanto mundo entre os espelhos. Leibniz fala de "espelhos vivos" que retratam o mundo enquanto mundos um após o outro, de modo monádico.)

A diferenciação de Husserl entre experiência passiva e ativa torna visível, numa tomada instantânea, com qual problema topamos na questão da experiência. A condição de uma "corrente de vivência" comum encobre, porém, de novo esse paradoxo reduzindo a experiência a priori a uma ordem preestabelecida, dentro da qual somente o pensável é também experimentável. Levanta-se, entretanto, a pergunta quanto a se justamente o pensar não estaria em condições de querer pensar e, então, orientar sua força, ao invés do mero pensar isso. Husserl pressupõe que, na corrente de vivência comum, encontrem-se presentes, de antemão, as possibilidades das experiências pensáveis, para que possam ser após desenvolvidas. Isso lembra, claramente, a doutrina platônica do homem, ao qual todas idéias são já inatas, para serem trazidas à tona através da arte da maiêutica. Para ísso, precisa-se certamente de um outro, de cujas palavras o homem dependeria para desdobrar suas idéias. Também essa doutrina de imanência está na dependência de uma exigência de fora, para poder desdobrar-se. Para Husserl, essa dificuldade, por certo, não serve de motivo para projetar uma ética, já que a complexidade fenomenal de mundo desdobra-se de modo lógico. Os fenômenos encontram-se interligados por uma lógica, cuja evidência está presente no Ego.

\section{O Ser-com, em Heidegger (Mit-Sein)}

Ser e Tempo, de Heidegger, remete, em algumas passagens, ao "Ser-com" do outro, em Husserl, sem, na verdade, mencionar explicitamente seu nome. A ontologia heideggeriana do "Ser-com" refere-se à fenomenologia de Husserl, mas sua transformação da fenomenologia numa ontologia fundamental passa ao largo da crítica implícita perante seu mestre em filosofia. Se pudermos falar, no caso da Fenomenologia de Hegel, de uma tentativa de ver a constituição da consciência entretecida em um contexto social, temos de perguntar, em se tratando de Heidegger, como antes dele em Husserl, se a socialidade seria de fato importante para a consideração da inclusão do outro. À leitura de Heidegger, coloca-se a pergunta despretensiosa: tem a ontologia, de modo geral, alguma utilidade enquanto fundamentação de uma filosofia social?

6 Idem, p. 153. 
Vários intérpretes tornam produtivo esse contexto sendo, finalmente, Levinas aquele que - junto e, mesmo assim outro que além de Sartre - liga-se em particular ao pensamento de Heidegger, enquanto leva a lógica do Ser, nas conseqüências imanentes que esta tem em Heidegger, contra a pretensão fundamental desse filósofo. $\mathrm{Na}$ discussão de Levinas com a ontologia heideggeriana, torna-se claro sobretudo aquilo que diz respeito à implícita proximidade de Heidegger com a filosofia de sistema, de Hegel. As considerações de Heidegger quanto a um horizonte pré-racional, as quais subjazem à entrada em cena do espaço racional do pensar, separam-no - tal como Husserl - das conclusões da razão em Hegel. A abertura dos pontos de partida em Heidegger e Husserl é, para Levinas, o impulso em direção a considerações mais longas por estes autores terem renunciado ao fechamento do pensamento.

O "Ser-com" do outro, em Ser e tempo de Heidegger, entra em cena num momento, em que o Ser já se mostra no "Ser-ai" (Dasein). Por isso, o outro abre-se através do "Ser-ai" enquanto um "Ser-com", o qual empresta, afinal, à pergunta pelo "Quem-é", o seu significado em geral. É só pelo "Ser-com" que o "Ser-ai" é em certo sentido um atributo do Ser mundano e, enquanto tal, um momento do Ser-aí. Tal como em Husserl, Heidegger ${ }^{7}$ não toma nesse passo como ponto de partida a experiência do "Eu penso"; ele fala, porém do "Ser indubitavelmente dado" do "Eu", o qual "em sua própria casa", encontra-se no "aqui". A determinabilidade ôntica dessa pressuposição ontológica fica, necessariamente, "encoberta"8 e precisa, por isso, ser considerada, também, não como certeza substancial (enquanto substância finita do corpo extenso ou do substrato biológico). Essa estrutura, no entanto, integra-se na determinação do Ser-aí. O Ser-aí é, assim, determinado a partir de um lugar que não pode estar em outra parte mas aqui, onde está o "Eu". Seguindo-se este raciocínio, faz-se claro que a pergunta pelos outros (Heidegger o formula no plural) tem o seu ponto de partida no Ser-ai; e ela coloca-se, nessa medida, com razão enquanto uma exigência que parte do "Eu" em relação aos outros; Eu esse, que só de modo formal compreende-se como identidade. Daí que permaneça também formal qualquer autodeterminação fenomenológica do Eu que, enquanto Ser-aí, é apenas expressão de um estar. Com isso, a estrutura completa está já também dada. O Ser-aí apresenta-se como um Ser-com, sendo, portanto, já e enquanto tal um Ser-aí-com (Desein-mit). No momento em que se desdobra um aí do Ser, a ele é dado também um com.

"O mundo do Ser-aí é mundo-com", escreve Heidegger; pois, o Ser-no-mundo significa, desde sempre, ser já outro. Através do Ser-com, o Ser saiu de si. "Os outros não são encontrados, pelo conceber diferenciador, de antemão, entre o sujeito próprio, já existente, e os outros sujeitos que aparecem", continua Heidegger "eles se encontram a partir do mundo [...]". ${ }^{9}$ Assim, o surgimento dos outros revela-se enquanto Ser-no-mundo, o qual não só toca a própria identidade, mas funda, simultaneamente, identidade. 
A pergunta anteriormente colocada por Heidegger, pelo "Que é do Ser-ai", só se abre através do "Ser-com" dos .outros. Mesmo opondo-se à fundamentação fenomenológica de Husserl, Heidegger chega, num primeiro passo, a um resultado análogo. Pois o outro avança para a relação comigo através de um fundo comum que antecede a ambos. Na medida em que o outio emerge como momento do Ser-aí, cujo desdobramento, em princípio, acontece "aqui", o outro torna-se um momento desse esboço. Michael Theunissen comenta essa passagem do seguinte modo: "O outro é o projetado de meu projeto, e não se diferencia, nesse ponto, do Ser-à-mão. Conseqüentemente, o Ser-junto torna-se ainda mais exclusivo do que em Husserl, no essencial representado segundo o modelo de minhas relações com o outro, e não segundo o modelo do outro em relação a mim [...]. Na medida em que o outro, como todos os demais seres dentro do mundo, vêem-se aprisionados no meu projeto do mundo, rouba-lhe Heidegger, tanto quanto Husserl, a sua estranheza e insubordinação."10

A comparação com Husserl é particularmente conclusiva com vista a Levinas, porque Heidegger remete a um princípio ontológico, o qual, em Husserl, é parcialmente rompido, porque ele concebe a experiência simultaneamente como acontecimento. E com isso torna visível uma ruptura, a qual Heidegger só reconhece na diferença entre Ser e Ser-aí, logo apenas na perspectiva da unidade ontológica. A crítica feita a Heidegger, de ter posto o todo, primeiro em nivel ôntico, para só após desenvolver uma diferença ontológica, é inteiramente pertinente. Ainda assim, a crítica de Levinas torna, ela própria, evidente que Heidegger não leva adiante, de modo plenamente conseqüente, o seu próprio projeto. Pois a diferença ontológica aponta, no fundo, a um abismo ôntico, que não é nem Ser, nem Não-Ser. Na experiência do outro, sou confrontado com esse abissal. Cada encontro com o outro no "Ser-com" acontece, porém, somente na e à base da estrutura ontológica, no seu todo, ao passo que cada fundamentação socialontológica risca seus próprios fundamentos devido ao fato de o Eu e o outro só expressarem um Ser-aí que apenas contém seu próprio, sem poder entretanto ele próprio ser tal. A diferença não é uma tal que se dê entre mim e o outro, senão entre o ser e o projeto que eu imagino. Esse projeto desfigura o encontro.

É interessante que Heidegger, em detrimento da pergunta pelo encontro com o outro, chegue a conclusões que acionam "a gente" (man). Através do fundamento comum do Ser, todos são afinal os outros dos outros, formando, assim o "Ser-junto cotidiano". Essa é a conseqüência do "Cuidado em relação à diferença de um contra os outros", através do que, no fundo, cada um procura a distância que promove, de certo modo, a seqüência de um após o outro, isto é, a separação. "Porém, nessa distância que pertence ao Ser-com, encontra-se algo mais: o Ser-aí encontra-se enquanto Ser-junto cotidiano, sob a tutela dos outros. Não o Ser-aí é ele mesmo, os outros the tiram o Ser... Os outros não são, neste caso, outros determinados... O Quem-é não é esse ou aquele, não a gente mesma, e não alguns, nem a soma de todos. O Quem-é é o neutro, é a gente."11 A sociabilidade produz, portanto, distâncias que levam, para assim dizer, à neutralização. A exclusividade

10 Theunissen, Der Andere, p. 168.

11 Heidegger, op. cit., p. 126. 
do Egjo, ainda afirmada por Husserl, cai inteiramente fora do olhar em Heidegger, ou seja, diante do olhar, cai em imperceptível "ângulo morto". Único é o Ser, mesmo ali onde ele se desdobra no Ser-aí. Mas ele se torna assim necessariamente um Ser-aí-com, que põe todos os outros em relação mútua trazendo com isso, também, à dúvida aquela ainda enfaticamente afirmada por Husserl. Ali, onde o Eu afirma estar consigo, ele se degradou à cotidianidade, no sentido de Heidegger, mesmo que, na gênese do desdobramento do Ser, ele parta do princípio que a "pergunta pelo Quem-é" só pode ser feita no "aqui", isto é, da consideração de que o outro seja o esboço de meu-outro à frente. Em conseqüência disso, o chegar a realizar-se do encontro pressupõe o esboço. O encontro ele mesmo é a expressão do esboço que o $\mathrm{Eu}$ faz do outro para si, a fim de representar para si uma comunidade.

Levinas, pelo contrário, afirma, com razão, que, por causa disso o encontro fracassa já que cada um encontra apenas a si mesmo, e não o outro. Se cada um já sabe o outro, escapa ele também de sua experiência imediata.

\section{4 "A experiência do outro antes de toda a experiência", em Levinas}

O pensamento de Emmanuel Levinas remete explicitamente à Fenomenologia de Husserl e à Ontologia heideggeriana. A ambos, Levinas deve impulsos essenciais para sua filosofia social, cujos conceitos de sociabilidade e moralidade diferenciam-se categoricamente daquilo exposto nas idéias até agora abordadas. Ao fundo, a especificidade da filosofia de Levinas baseia-se na idéia de uma experiência, pressuposta à experiência a qual se viu na filosofia de Hegel, de modo exemplar, enquanto reflexividade suspensa, a fim de poder ser denominada. Também o hegeliano Adorno tentara sublinhar a força da dialética negativa, contra uma dialética automatizada que incorpora a si cada experiência não disponivel, para dela apropriar-se. Dessa maneira - segundo os escritos de Adorno - o indominável do "Não-idêntico" deveria ser defendido frente à perfeição da dialética hegeliana. A intenção de Adomo é motivada, de fato, por um impulso semelhante àquele da filosofia de Levinas, a saber, proteger a experiência do pensamento contra sua inclusão totalitária. Ele leva, por isso, à experiência prefigurada a ser confrontada com o impulso pelo "Não-idêntico".

Essa comparação breve deve cumprir, neste momento, o objetivo de mostrar que a própria tradição do pensamento dialético, ligado a Hegel, tem dificuldade de encontrar saídas imanentes do problema da inclusão totalitária pelo sistema de Hegel. Adorno, tal como E. Bloch, tenta defender o movimento dialético, contra seus procedimentos petrificados. Para Levinas, no entanto, o problema está na própria dialética, que executa juízes aos quais é pressuposta a validade de um sistema de razão comum. Essa pressuposição é posta não somente em dúvida por Levinas, mas será ainda responsabilizada pela aceitação da pressuposição de uma ordem comum que leva ao fracasso da ética ocidental, por sua vez, baseada na idéia de uma razão única cujo ápice foi atingido na filosofia de Hegel. Com esta crítica, Levinas poderia contar com a complacência de Adorno que acrescentaria, porém, oferecer a filosofia de Hegel o melhor instrumentário para criticar dialeticamente o uso dogmático da idéia da razão. Adorno tenta salvar, juntamente com 
a Dialética, o instrumentário genuinamente crítico - sobretudo contra o discurso da fenomenologia e ontologia, por ele repudiado enquanto "jargão da autenticidade". 12

Mesmo que me pareça fazer sentido uma comparação com a crítica de Adorno, Levinas se coloca explicitamente dentro da tradição por ele tão violentamente contestada. Sua disputa remete, antes de tudo, a Husserl e Heidegger. Ai, as rejeições da ontologia heideggeriana têm muita semelhança com sua critica a Hegel, ainda que essas referências ofereçam muito mais possibilidades para o desdobramento de um conceito de experiência transcendental. Essa experiência transcendental, no entanto, evita retomar uma ontologia pré-kantiana; pelo contrário, remonta à deontologização desenvolvida pelo próprio Heidegger, ligado a Kant, a fim de sacudir o Próprio através da exigência do outro. Se o Ser não mais configura o fundamento, o Ser-com torna-se, também, uma farsa. O Próprio não se poderá sequer autodeterminar como um Quem-é, através do outro, porque não há mais fundamento que seria para que a fenomenalidade do Eu e do Tu pudesse ser experimentada. A perda do Ser constitui, muito antes, o ponto de partida da experiência para o qual já não existe nome algum. A ontologia kantíana o nomeia o Proto-fundamento (Urgrund). Ao meu ver, a referência imanente a Kant - até agora pouco considerada - é um momento essencial do pensamento filosófico de Levinas.

A ética de Levinas baseia-se na primazia da experiência do outro que permanece inacessiviel ao próprio pensamento. Levinas remonta à fenomenologia de Husserl, ao abandonar sua imanência na tese segundo a qual o projeto de uma experiência não seria passivel de esclarecimento por um espaço de experiência pré-julgado, senão pelo chegar a mim do outro, o qual, só ele, abre o espaço para $\mathrm{mim}$. No intuito de conseguir uma tal abertura, exige-se a entrega absoluta, um expor-se que impede qualquer tomada de posição. Não resta sequer a escolha de uma posição, eis porque tampouco um ser qualquer desenha o fundamento.

Cada caracterização que descreveu a relação entre mim e o outro, enquanto experiência passiva e ativa (Husserl), enquanto senhor e escravo (Hegel) ou enquanto existência e Ser-aos-cuidados (Heidegger), são tentativas posteriores do domínio conceitual dessa experiência. É essa experiência que subjaz a qualquer determinação, escapando, também, por sua vez, de qualquer juízo racional. Mesmo quando escapa, assim, à consciência, as pegadas, os traços dessa experiência são reconhecíveis enquanto seu efeito na consciência. Pois, eu posso saber que me volto ao outro, posso saber que amo, mesmo quando eu, entretanto, não posso perceber a causa disto. Se o outro fosse redutível, para mim, a uma finalidade determinada, eis que ele se tornaria elemento de um cálculo teleológico determinável no decurso do mundo. Com isso, não apenas o passado seria redutível a uma seqüência de determinações de fins, mas o próprio futuro previsível. Um traço da experiência do outro é a linguagem cuja função, para Levinas, não se cinge à troca de informações. Antes, é preciso colocar a pergunta pelo motivo que leva, em geral, à troca de informações. Essa pergunta tem, de fato, um tal motivo, embora a resposta não esteja por isso, garantida. Pelo contrário, a pergunta pres-

12 Ver T. Adomo, Jargon der Eigentlichkeit - Zur deutschen Ideologie. 
supõe a possibilidade de uma resposta, empurrando-se a si mesma ad absurdum, pois sua resposta jamais acontece (fica fora). O motivo do falar consiste em mais do que na mera troca de signos. À fala subjaz o desejo de se dirigir ao outro. Esse desejo, porém, não cumpre nenhum objetivo no sentido de ser determinado racionalmente. Pois, o cumprimento de uma finalidade pressuporia, de antemão, existir consenso implícito sobre um fim que relacionasse dois parceiros do diálogo, um ao outro. Podemos dizer que esse não é o caso, porque falamos um com o outro, na maioria dos casos, sem poder saber qual a resposta que recebemos. A curiosidade e o interesse pelo outro orientam-se mais no sentido do experimentar do que do esperar.

Aplicado, concretamente à nossa situação: Eu não sei o que vocês farão com as minhas palavras ou aquelas de meu tradutor (e esse é mais um problema). Eu, porém, falo para vocês, embora não vá ter nunca a certeza quanto ao significado que minhas palavras terão para vocês. Em primeira linha, vocês acolherão minhas palavras porque se sentem solicitados. É só essa sensação que me possibilita esperar o empenho de vocês em compreender. Tal compreensão será, possivelmente, algo outro do que o por mim esperado. Mas mesmo que vocês me compreendam de modo outro do que o por mim intencionado, nós nos teremos experimentado, ainda assim, no diálogo, enquanto outros. O encontro primordial, no diálogo, não pode ser reduzido à troca de informações. Vocês podem compreender minhas palavras de um modo outro do que o por mim intencionado. Mais ainda, afirmo que vocês compreendem minhas palavras de modo diferente, pois se de fato não fosse assim, eu teria de supor, que vocês só representam uma duplicata de mim. Talvez seja uma conseqüência feliz da confusão babilônica da linguagem, que nos esforcemos em relação ao outro, já que a linguagem nos separa, linguagem da qual esperávamos entendimento. Pelo contrário, a conseqüência de uma compreensão abrangente levaria a uma solidão irreversivel, na qual o indivíduo ficaria separado do outro, justamente porque ele sempre saberia antecipar o que o outro tem a dizer. $\mathrm{O}$ desejo de falar, porém, articula-se na própria palavra, que expressa, em geral, a experiência do outro.

Concretamente: vocês encontrarão nas minhas palavras outros sentidos além daqueles por mim injetados, e é isso exatamente, que torna provocante o diálogo. Impensável seria a linguagem se ela não remontasse ao desejo de voltar-se a um outro do que eu sou. Sem significado seria o falar com alguém cuja resposta já soubesse prever. Que eu não o saiba e ainda assim fale, exige não só a coragem, que cada pessoa que fala tem de ter. Mostra-se ai, também, o traço da experiência de que um outro veio-me ao encontro, antes de eu poder dizer: "eu penso". É por isso que vocês estão aqui. Porque também vocês esperam, possivelmente, experimentar algo, sobre os quatro projetos filosóficos, nos quais vocês engancharam expectativas. Expectativas essas que terão de deixar cair ou a que terão, no momento, de renunciar, devido ao deslocamento que elas sofreram através de minhas palavras. Para que minhas palavras os atinjam, é preciso que nos seus ouvidos penetrem mais do que a mera informação que elas contêm. $\mathrm{Na}$ experiência do outro, como Levinas a compreende, eu serei permanentemente ferido na minha 
integridade, porque o outro chama-se a si mesmo na lembrança para mim. Essas são experiências, às quais estive muitas vezes exposto e sinto-me delas também ferido.

Levinas destacou esta experiência sobretudo em relação ao dizer. A diferenciação entre o dizer e o dito abre uma diferença, através da qual se percebe, até que ponto a "experiência antes de qualquer experiência" é pressuposta, a fim de que se dê, em geral, uma identificação disso, que é o Eu e disso que é o Outro. A pista da experiência é a própria palavra, que se mostra como o desejo entre as pessoas, de serem ouvidas pelo outro.

\section{Perspectiva}

A curva que vai de Descartes a Levinas foi conscientemente traçada de modo muito amplo. Mesmo assim, consistente, pois no entretempo, o espaço do pensamento foi usado em projetos fundamentados no intuito de encontrar o caminho para o outro. As quatro perspectivas por mim salientadas correspondem estreitamente ao salto cartesiano do "eu penso", que quis deixar atrás de si o pensamento metafísico herdado. Suspeito que dentro desse horizonte por mim esboçado, em poucas pinceladas, abra-se um paradoxo intransponivel para um sujeito que se queira fundamentar a si mesmo. A idéia da autofundamentação não é algo por si mesmo compreensível, tal como o provam as inúmeras tentativas da filosofia do sujeito. O sujeito - eis como o poderíamos dizer - não se compreende por si mesmo. Justamente aquele que diz "eu penso", dirige-se, com essas palavras, a um outro, que testemunha as palavras. O testemunhar das palavras é, porém, ele mesmo expressão de que o outro é a oportunidade para que o Eu pensante se dirija, falando-se, a um outro. De modo inverso, porém, Levinas é confrontado com o problema de que os recipientes de suas palavras empenham-se, de modo racional, em descobrir a verdade de seus argumentos. Nessa medida, precisa-se para a mediação da dimensão da experiência, por ele des-coberta, de um compreender, que só após, aprende a ler os traços do que foi antes. E se eu apresento a vocês essas matérias complexas, desejo, naturalmente, que vocês sigam a lógica de minha argumentação. Com isso, a filosofia de Levinas revela um problema, o qual, em princípio, só a imaginação da razão ataca; esse problema está na afirmação da razão de que se bastaria a si mesma. As dúvidas referentes a essa presunção continuam válidas, mesmo depois das propostas cartesianas para sua solução.

\section{Referências bibliográficas}

ADORNO, Theodor W. Jargon der Ejgentlichkeit - Zur deutschen Ideologie. Frankfurt/M: Suhrkamp, 1964.

BENJAMIN, Jessica. The Bonds of Love. Psychoanalysis, Feminism and the Problem of Domination.

New York: Pantheon, 1988.

HEGEL, G. W. F. Die Phänomenologie des Geistes. In: Werke, Bd. 3, Frankfurt/M: Suhrkamp, 1970. HEIDEGGER, Martin. Sein und Zeit. Tübingen: Neimeyer, 1984.

HUSSERL, Edmund. Cartesianische Meditationen. Hamburg: Meiner, 1987.

LEVINAS, Emmanuel. Totalité et Infini: essai sur l'exténiorité. La Haya: Martinus Nijhoff, 1961.

THEUNISSEN, Michael. Der Andere. Berlin-Paris-New York: De Gruyter, 1977. 